\title{
Mobile Cloud Learning based on User Acceptance using DeLone and McLean Model for Higher Education
}

\author{
Kristiawan Nugroho ${ }^{1}$, Sugeng Murdowo ${ }^{2}$ \\ Computerized Accounting \\ AMIK Jakarta Teknologi Cipta \\ Semarang,Indonesia
}

\author{
Farid Ahmadi $^{3}$, Tri Suminar ${ }^{4}$ \\ Faculty of Education \\ Universitas Negeri Semarang \\ Semarang,indonesia
}

\begin{abstract}
Mobile learning has been used in the learning process in several tertiary institutions in Indonesia. However, several universities have not been able to implement mobile learning due to the limitations of computer and network infrastructure. Cloud computing is a solution for agencies that experience limitations in computer infrastructure in the form of internet-based services for their customers. This paper discusses the implementation of mobile cloud learning which is a combination of mobile learning technology and cloud computing using the renewal DeLone and McLean Model which is a successful model to measure how important the implementation of a mobile cloud learning system is. The results showed that from the $F$ test results obtained Fcount of 13,222, then Fcount> Ftable (13,222> 3.01), then Ho was rejected and $\mathrm{H1}$ was accepted. So it can be concluded Information Quality, System Quality, and Service Quality together affect the Intensity of Use.
\end{abstract}

Keywords-Mobile learning; cloud computing; DeLone; McLean; model

\section{INTRODUCTION}

The use of information technology in education has been widely carried out by various universities throughout the world. Elearning is an electronic learning tool as a learning aid tool that has been successfully applied in universities in several countries including Yemeni University in Yamen [1]. Today there has been a transition from technological forms from web base applications to mobile applications makes it easier for students to get learning wherever they are. Mlearning is a vital component of educational technology in higher education, students can learn, collaborate, share ideas about lessons using technology development on the internet [2]. Students can do learning activities without having to be in class, they can learn and interact with the material and lecturers whenever and wherever they are. The application of mobile learning technology is not only for ordinary students, but Mlearning is also applied to students who have dyslexic disorders. By adjusting multimodal functionality, Mlearning can improve the learning abilities of students with dyslexia by almost 30\% in learning activities [3]. Tablets, PDAs and smartphones have become a part of human life, this equipment helps human activities, especially in the field of education. The use of mobile learning in modern learning is increasing, the increasing use of smartphones, the development of cellular networks and the global internet are increasingly increasing learning acceptance by using electronic means[4].

The use of mobile learning applications has been applied from the level of kindergarten education[5] up to undergraduate education[6]. Some countries such as South Korea, the US, Japan, Taiwan, Malaysia, Singapore, the European Union, and Australia have been able to utilize mobile devices in a learning environment quite effectively, they have benefited from increased efficiency to ease of accessibility of education to remote areas[7]. Research on Mobile Learning is growing by combining with Cloud Computing (CC) technology which is a distributed computer group (mostly data centers and servers) that provide demand resources and services using internet media[8], $\mathrm{CC}$ is a new technology paradigm that helps provide infrastructure with the specifications needed by an organization including universities.

The three services provided by CC are Infrastructure as a Service (IaaS), Platform as a Service (PaaS) and Software as a Service (Saas). By using the three CC infrastructures above, a university does not have to have infrastructure such as servers and storage areas. big data in running online learning. The development of research on Mobile Learning using Cloud Computing has been applied in various fields of life. Research on mobile cloud computing among others was conducted by Dhanalakshmi who discussed several advantages of using mobile cloud computing compared to traditional mobile learning[9]. In addition, research on the use of mobile cloud computing is also conducted on students who have dyslexia [3], They build interactive multimodal interfaces to facilitate dyslexia students in learning. In addition to the world of education, Mobile cloud learning is also applied in the world of health. Several types of research are to monitor the risk of coronary heart disease sufferers using the Adaptive Neuro Fuzzy Inference System / ANFIS method [10], MCC implementation is also carried out in stroke patients monitoring using classification techniques in Artificial Neural Network (ANN) which produces applications to monitor the condition of stroke sufferers with an Android-based application[11]. Problems and challenges in implementing mobile learning include the high costs associated with equipment, connectivity, maintenance, technical support [12]. 
This paper discusses the design and implementation of mobile learning using cloud computing technology known as Mobile Cloud Learning in universities in Indonesia using the Delone and Mclean (D\&M) method. The D\&M method is used to find out the most influential factors in the use of Mobile Cloud Learning (MCL) so that the implementation of MCL can be optimally implemented in learning in tertiary institutions.

\section{RELATED WORKS}

\section{A. Mobile Learning}

Mobile learning is a modern learning technique that can be done through wireless devices such as mobile phones, PDAs, laptops and hand held devices[13]. Various researches on mobile learning have been carried out using mobile devices including PDAs[14, p.], however limited screen and memory factors hamper enough comfort in the learning process. Research on the weather carried out by Cloughet al. shows that statistically the use of mobile learning has proven to be effective compared to studies that only use survey methods alone[15]. In other studies of mobile learning involving students Min Juan Wang stated that learning activities using mobile learning are better than conventional methods due to intellectual, emotional and behavioral involvement in using this technology learning[16].

The satisfaction of educated participants and their independence in using system functions in mobile learning have also been implemented in a learning activity involving 152 participants[17] In 2011 Gwo-Jen Hwang conducted an experiment on a course containing local culture in Taiwan regarding effectiveness in a learning environment that uses mobile learning. The results of the research show that the use of Mlearning can increase student interest and learning achievement [8]. Learning with mobile learning is also done by forming Whatsapp groups that for 40 days interact in the learning process[18]. The results of the study show that students according to students learning with Whatspp Mlearning are interesting and beneficial to them.

Research on the implementation of mobile learning conducted in Oman involving students from 56 universities also shows that the level of awareness and acceptance of students shows a good level which means that students are interested in using smartphones in learning[19]. Kattayat in 2017 conducted research on the implementation of mobile learning in a number of students. The results showed that learning techniques with mlearning could improve achievement[20].

\section{B. Mobile Cloud Computing}

Mobile Cloud Computing (MCC) is a technology concept that combines cloud computing technology, secular technology and computer network utilization [21]. Khan stated that since 2008 there were 42.8 million mobile cloud computing subscribers who are expected to grow to 998 million subscribers in 2014 [22]. Several studies that have been carried out in utilizing cloud computing technology include
Kotwal stating that MCC is an amalgamation of mobile technology with cloud computing that provides cloud-based services for web and mobile users[23], Other studies conducted by Kumar and Rajalakshmi stated that MCC technology has focused on cloud security issues that exist in a variety of mobile devices[24]. Shamim believes that in a study around 2015 there would be 240 million businesses that use cloud computing services via mobile devices which would generate revenue in the MCL business of $\$ 5.2$ billion[25]. The architecture of mobile cloud computing can be seen in Fig. 1.

\section{DeLone and McLean Model (D\&M Model)}

The Delone and Mclean model is an information system model that was created in 1992[26]. D\&M Model is a framework that functions to measure complicated dependent variables in research on information systems, in this method will be discussed about the influence of system quality and information quality on user usage and satisfaction[27]. Some research using the D\&M model, among others, was carried out by Lee who examined what factors influenced the trust and satisfaction with the implementation of mobile banking in Korea[28]. This study uses the D\&M model in assessing 3 factors: system quality, information quality and interface design quality, using 276 valid questionnaires from mobile Bangking customers. The results of the study show that system quality and information quality significantly influence customer trust and satisfaction while design quality the interface does not affect customer trust and satisfaction. In the field of health, Bossen examines the methodological approach and the results of the evaluation of electronic health records (EHR) at hospitals in Denmark[29]. The results of the study explain that overall the staff has a positive impression in implementing the EHR, Performance, reliability, time response, login and all support can be received. In 2017 Mahmoodi applied the D\&M method in the field of education, the Virtual education system (VES) was evaluated using the D\&M model, resulting in a conclusion that the quality of the system had a large impact. the level of $68.8 \%$ [30].

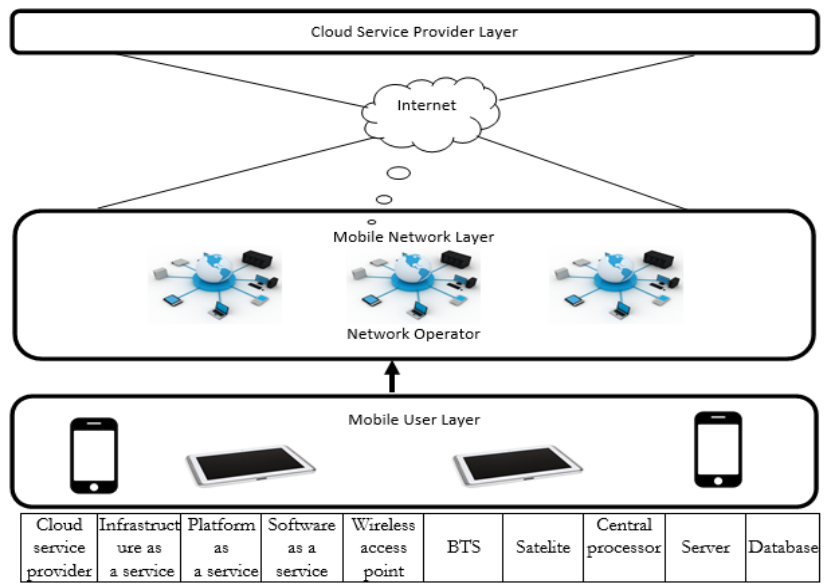

Fig. 1. The Mobile Cloud Computing Architecture (Source: Talal H. NOOR, 2018). 


\section{SYSTEM DESIGN AND IMPLEMENTATION}

\section{A. Proposed Method}

The proposed method in the research regarding the implementation of mobile cloud learning can be seen in Fig. 2.

Fig. 2 above is the methodology used in research on the implementation of mobile cloud learning. Students and lecturers who are users of the system access the application using smartphones or tablets through the public network that can be accessed via data packages or wifi. Application is a combination of the concept of mobile learning in which there are several learning facilities in the form of downloading and uploading material, forums and quizzes combined with the concept of cloud computing which can use 3 services, namely, SaaS (Software as a Service), PaaS (Platform as Service) and IaaS (Infrastructure as a Service). This mobile application is evaluated using the DeLone and McLean Model to measure the level of acceptance of applications which include several factors namely Information Quality, System Quality, Intention to Users, User Satisfaction and Net Benefits.

\section{B. System Design}

The design of mobile cloud learning systems used OOA (Object Oriented Analysis) which is a modeling technique that combines data and processes in an object. The development of OOA techniques in this application uses Unified Modeling Language (UML) which is described in the form of use case diagrams, sequence diagrams and class diagrams

\section{Design of System}

The design of a mobile cloud learning application is illustrated in the use case diagram described in Fig. 3.

Fig. 3 above shows the relationship between three actors, namely student, lecture and admin who interact with each other in a system consisting of registration processes, learning materials, online studies, discussions, quizzes, examinations, smart notifications and teleconferences.

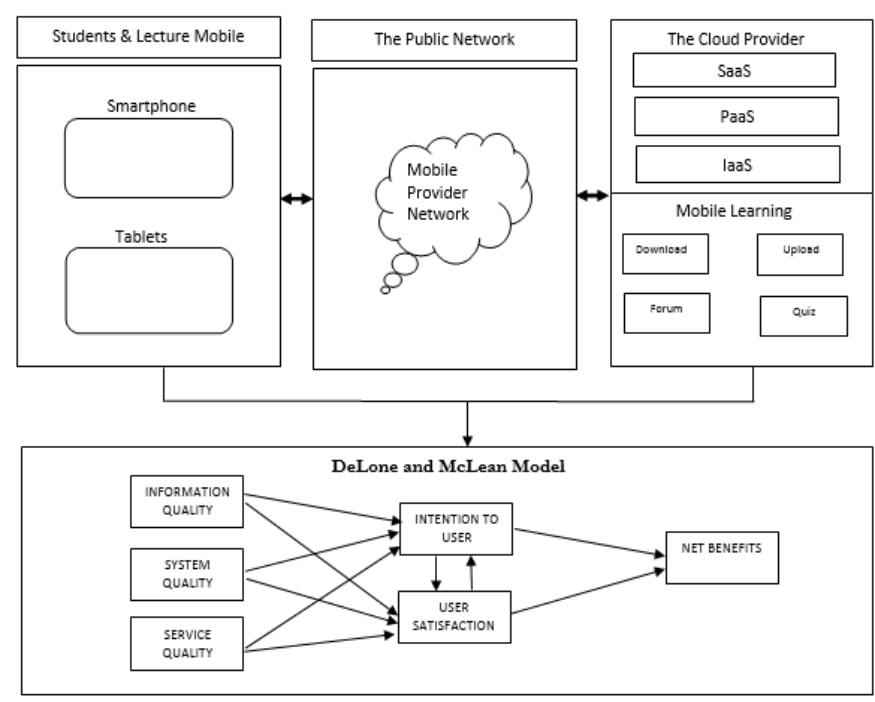

Fig. 2. Mobile Cloud Learning.

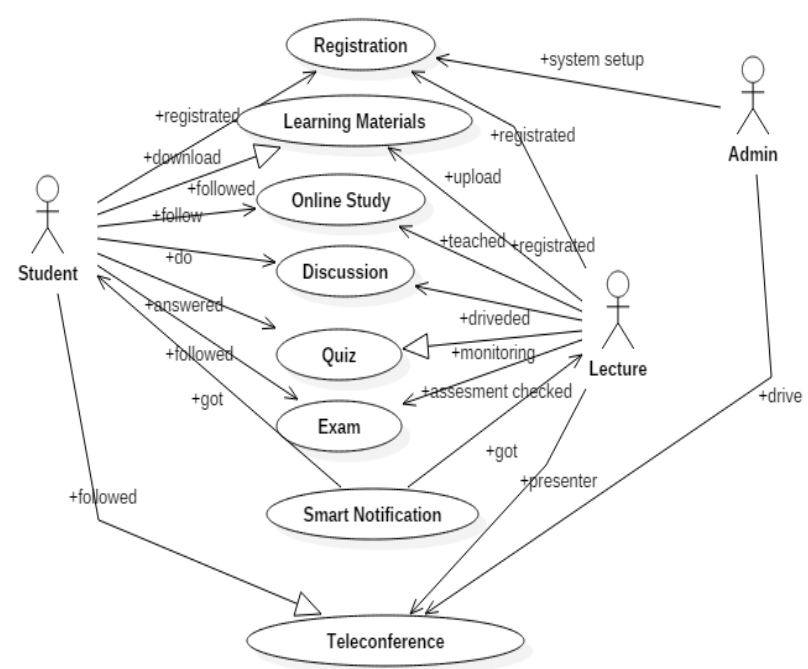

Fig. 3. Use Case Diagram.

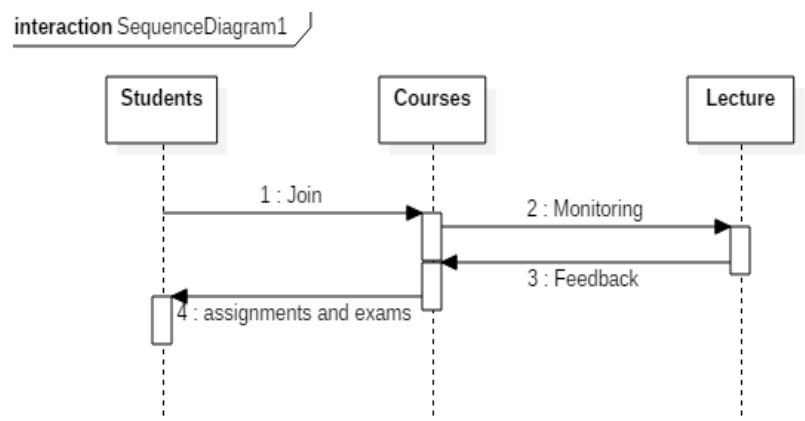

Fig. 4. Sequential Diagram.

Fig. 4 shows the design of a sequential diagram which includes the process beginning with students who join the courses held by each lecturer whose results will be evaluated with a quiz.

The class diagram of the mobile cloud learning system in Fig. 5 shows the relationship of classes that make up a system. Classes formed in this system include students, lectures, courses, discussions, online studies and quiz.

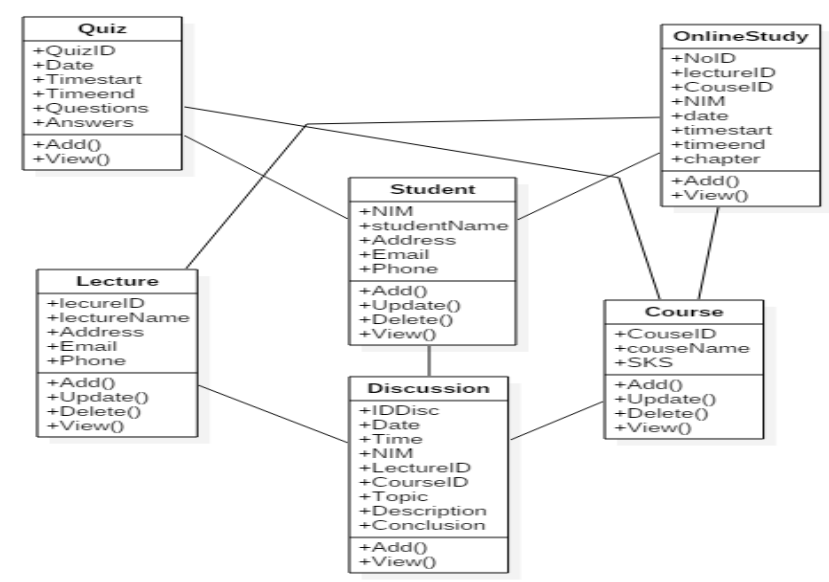

Fig. 5. Class Diagram. 


\section{RESULT AND DISCUSSION}

\section{A. Data Collections}

This study aims to determine the factors that influence the implementation of mobile cloud learning in universities in Indonesia. System testing is done by distributing questionnaires to the faculties of education outside the Universitas Negeri Semarang. Students run the mobile cloud learning application from the login process to the system dashboard, then students try to download material from the PNF Program Management course after which they work on a quiz consisting of several questions that must be answered one by one until the last question, the system will calculate the value achieved directly after students finish answering all questions and the results will be displayed in the system dashboard. After running the mobile cloud learning application students were distributed 28 questionnaires consisting of 32 questions to be answered where the questions contained regarding system quality, information quality, service quality, the intensity of use, user satisfaction and net benefits.

\section{B. Program Implementation}

The mobile cloud learning system is built using the Laravel framework and Android Studio web view. The results of making an application are shown in Fig. 6, 7, 8, 9 and 10 as follows.

Fig. 6 above shows the login application that must be filled in with a username and password that has been registered previously. If the user fills in a username and password that matches the one registered in the system, the user will be taken to the application's dahsboard menu display as shown in Fig. 7 as follows.

Mobile cloud learning users, namely students, can download material according to the class they are following as shown in Fig. 8.

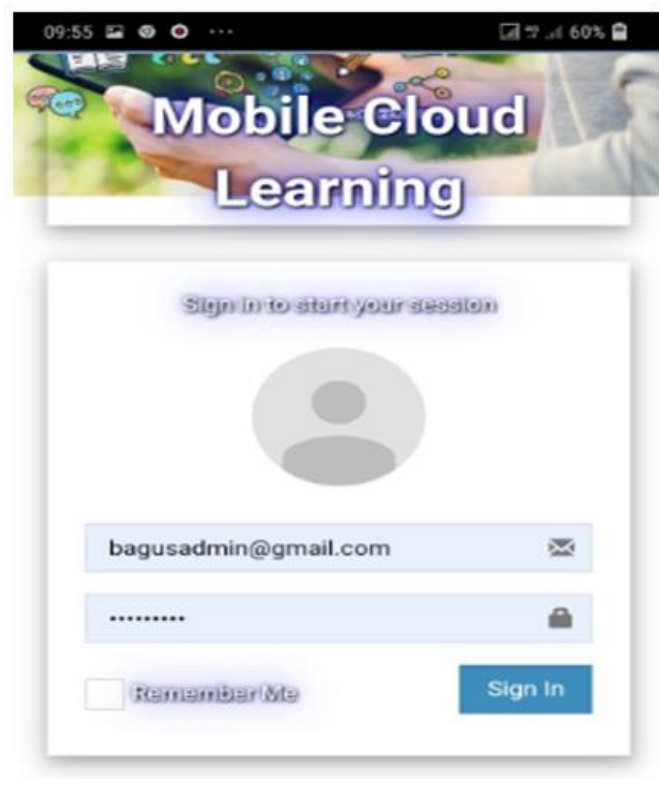

Fig. 6. USERS LOGIN.

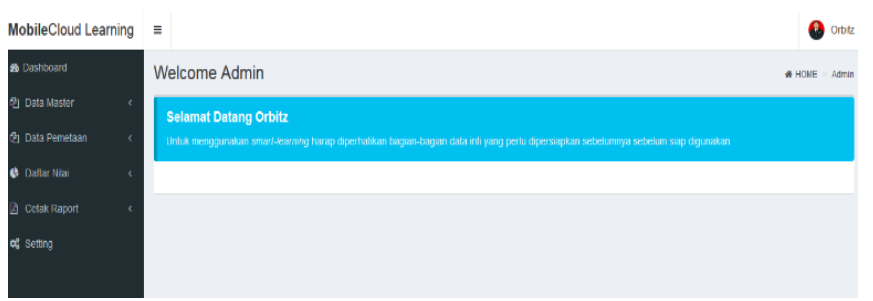

Fig. 7. DASHBOARD MENU.

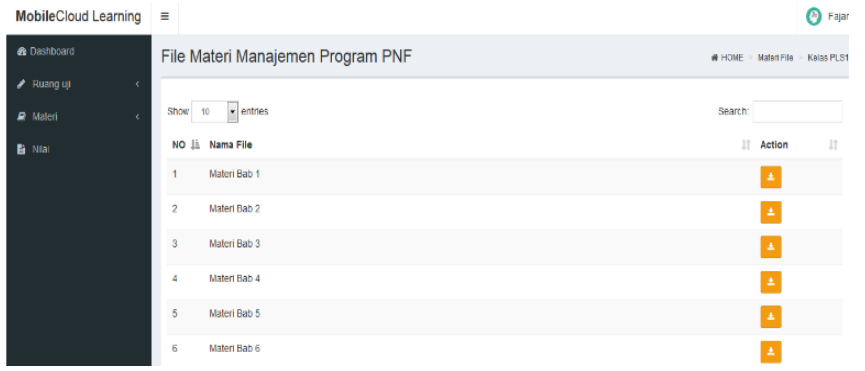

Fig. 8. DOWNLOAD MENU.

Fig. 9 shows a quiz application that can be answered by students after reading and studying the material they have downloaded previously. The questions in the quiz are randomized randomly according to the course taken by students.

After students answer all the questions in the quiz, the system will do the calculation and automatically give a value to the correct answer to the final result of the calculation as shown in Fig. 10.

\section{System Testing}

1) Test validity of measuring instruments: Validity shows the extent to which the measuring instrument is able to measure what you want to be measured. In testing the validity of using the Pearson Correlation technique, where the process is seen from the correlation value on the total value of the answers. The value in the answer row is compared with the $r$ table with a significance value of $5 \%$ and the number of samples 28 rtable is 0.374 as shown in Table I.

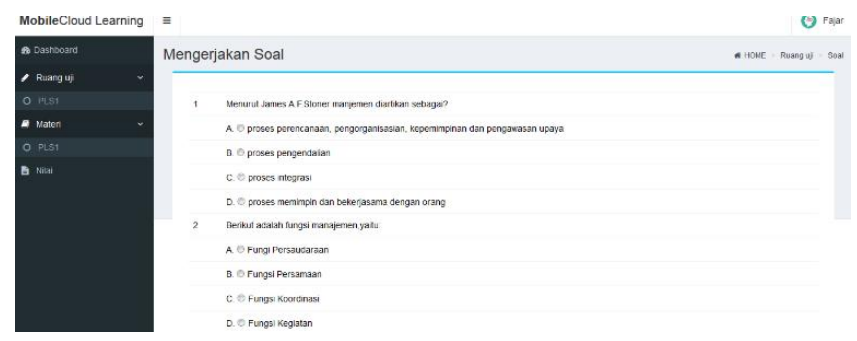

Fig. 9. Quiz MENU.

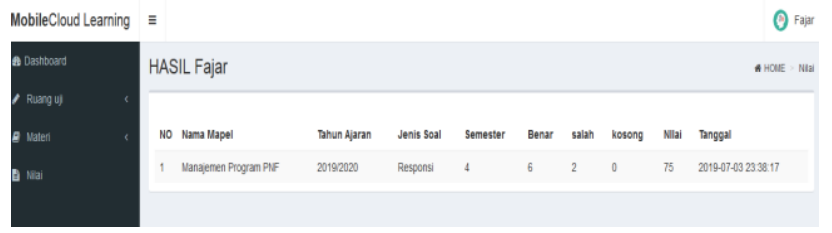

Fig. 10. QUIZ Result. 
TABLE. I. VALIDITY TEST RESULTS

\begin{tabular}{|c|c|c|c|}
\hline Variable & Rcount & Rtable & Description \\
\hline X11 & 0,762 & 0,374 & Valid \\
\hline $\mathrm{X} 12$ & 0,513 & 0,374 & Valid \\
\hline X13 & 0,716 & 0,374 & Valid \\
\hline $\mathrm{X} 14$ & 0,662 & 0,374 & Valid \\
\hline $\mathrm{X} 15$ & 0,751 & 0,374 & Valid \\
\hline X16 & 0,828 & 0,374 & Valid \\
\hline $\mathrm{X} 21$ & 0,774 & 0,374 & Valid \\
\hline X22 & 0,784 & 0,374 & Valid \\
\hline $\mathrm{X} 23$ & 0,81 & 0,374 & Valid \\
\hline $\mathrm{X} 24$ & 0,659 & 0,374 & Valid \\
\hline $\mathrm{X} 25$ & 0,305 & 0,374 & Not Valid \\
\hline $\mathrm{X} 26$ & 0,64 & 0,374 & Valid \\
\hline $\mathrm{X} 27$ & 0,578 & 0,374 & Valid \\
\hline $\mathrm{X} 28$ & 0,618 & 0,374 & Valid \\
\hline X31 & 0,66 & 0,374 & Valid \\
\hline X32 & 0,85 & 0,374 & Valid \\
\hline X33 & 0,835 & 0,374 & Valid \\
\hline X34 & 0,66 & 0,374 & Valid \\
\hline X35 & 0,865 & 0,374 & Valid \\
\hline $\mathrm{X} 41$ & 0,883 & 0,374 & Valid \\
\hline $\mathrm{X} 42$ & 0,76 & 0,374 & Valid \\
\hline X51 & 0,695 & 0,374 & Valid \\
\hline X52 & 0,837 & 0,374 & Valid \\
\hline X53 & 0,749 & 0,374 & Valid \\
\hline X54 & 0,56 & 0,374 & Valid \\
\hline X55 & 0,64 & 0,374 & Valid \\
\hline X61 & 0,589 & 0,374 & Valid \\
\hline X62 & 0,782 & 0,374 & Valid \\
\hline X63 & 0,584 & 0,374 & Valid \\
\hline X64 & 0,695 & 0,374 & Valid \\
\hline X65 & 0,525 & 0,374 & Valid \\
\hline X66 & 0,503 & 0,374 & Valid \\
\hline
\end{tabular}

The test results are declared valid if rcount $>$ from rtable, from the research variables there is 1 variable that is declared invalid, namely the Integrated Completeness Variable of the System Quality group

2) Measuring instrument reliability test: A reliability test in Table II is used to determine the consistency of measuring instruments that usually use a questionnaire. The reliability test is a continuation of the validity test where the items included in the test are valid items only. By using the 0.6 limits it can be seen whether the instrument is reliable or not. Provided less than 0.6 is not good, 0.7 is acceptable and above 0.8 is good.
TABLE. II. RELIABILITY TEST RESULTS

\begin{tabular}{|l|l|l|l|}
\hline No & Variable & CronBach's Alpha & N of Items \\
\hline 1 & Information Quality (X1) & 0.881 & 6 \\
\hline 2 & System Quality (X2) & 0.889 & 7 \\
\hline 3 & Service Quality (X3) & 0.908 & 5 \\
\hline 4 & Intensity of Use (X4) & 0.916 & 2 \\
\hline 5 & User Satisfaction (X5) & 0.893 & 5 \\
\hline 6 & Net Benefits (Y) & 0.846 & 6 \\
\hline
\end{tabular}

3) Joint regression coefficient test (f test) 1: Joint regression tests are used to determine the effect together between the dependent variable $(\mathrm{X})$ on the dependent variable (Y). The F Test results can be seen in Table III as follows:

a) Predictors (Independent): Information Quality, System Quality, Service Quality

b) Dependent Variabel: Intensity of Use.

Based on the $\mathrm{F}$ test results from the above table using a significance level of 0.05 and df 1 (number of variables -1) $\mathrm{df} 1=4-1=3$ and df $2(\mathrm{nk}-1)$ or $28-3-1=24$ (where $\mathrm{n}=$ number of respondents, $\mathrm{k}=$ number of independent variables) read from table F of 3.01.

For testing criteria if $\mathrm{F}$ arithmetic $<\mathrm{F}$ table, then $\mathrm{Ho}$ is accepted and if Fcount $>$ Ftable then Ho is rejected.

From the F test results obtained Fcount of 13,222, then Fcount> Ftable $(13,222>3.01)$, then Ho is rejected and H1 is accepted. So it can be concluded Information Quality, System Quality, and Service Quality together affect the Intensity of Use.

4) Partial regression coefficient test ( $t$ test): $T$ test is used to determine partially the independent variable (X) significantly influences the dependent variable (Y). Test results $f$ using multiple linear regression can be seen in Table IV as follows:

a) Independent Variable

$$
\begin{aligned}
& \text { X1 - Information Quality } \\
& \text { X2 - System Quality } \\
& \text { X3 - Service Quality }
\end{aligned}
$$

b) Dependent variable Y (X4)- Intensity of Use

Test criteria $\mathrm{T}$ test is that if the tcount $>$ ttable then $\mathrm{H} 1$ is accepted and Ho is rejected, and if the tcount <ttable then H1 is rejected and Ho is accepted.

TABLE. III. F TEST RESULTS

F Count Value

13.222

TABLE. IV. T TEST RESULT

\begin{tabular}{|l|l|l|}
\hline Variable & $\mathrm{t}$ count & $\mathrm{t}$ table \\
\hline $\mathrm{X} 1$ & 0.268 & 2.064 \\
\hline $\mathrm{X} 2$ & 2.040 & 2.064 \\
\hline $\mathrm{X} 3$ & 1.169 & 2.064 \\
\hline
\end{tabular}


For the value of $\mathrm{t}$ table can be seen from the statistical table with a significance value of $0.05 / 2=0.025$ and degrees of freedom $\mathrm{df}=28-3-1=24$ is 2.064 .

Following are the results of the description of each hypothesis:

1) Information quality variable test results that: Information Quality does not affect the Intensity of Use obtained from the Mobile Cloud Learning System. This is evidenced by the value of tcount <ttable $(0.268<2.064)$ which means $\mathrm{H} 1$ is rejected.

2) System quality variable test results that system quality: does not affect the Intensity of Use obtained from the Mobile Cloud Learning System. This is evidenced by the value of tcount <ttable $(2,040<2,064)$ which means $\mathrm{H} 1$ is rejected.

3) Time service variable testing results that service: Quality does not affect the Intensity of Use obtained from the Mobile Cloud Learning System. This is evidenced by the value of tcount <ttable $(1,169<2,064)$ which means $\mathrm{H} 1$ is rejected.

5) The regression coefficient together test(test f) - 2: Joint regression tests are used to determine the effect together between the dependent variable $(\mathrm{X})$ on the dependent variable (Y). The F Test results can be seen in table V as follows:

a) Predictors (Independent): Information Quality, System Quality, Service Quality, Intensity of Use

b) Dependent variabel: User Satisfaction

Based on the $\mathrm{F}$ test results from the above table using a significance level of 0.05 and df 1 (number of variables -1) df $1=5-1=4$ and df 2 (nk-1) or $28-4-1=23$ (where $n=$ the number of respondents, $\mathrm{k}=$ number of independent variables) read from table $\mathrm{F}$ of 2.8. For testing criteria if $\mathrm{F}$ arithmetic $<\mathrm{F}$ table, then Ho is accepted and if Fcount $>\mathrm{F}$ table then Ho is rejected.

Based on the F test results obtained Fcount of 9,255, then Fcount $>$ Ftable $(9,255>2.8)$, then Ho is rejected and H1 is accepted. So it can be concluded Information Quality, System Quality, Service Quality and Intensity of Use together affect the User Satisfaction.

6) Partial regression coefficient test ( $t$ test): $\mathrm{T}$ test is used to determine partially the independent variable (X) significantly influences the dependent variable (Y). Test results $f$ using multiple linear regression can be seen in Table VI as follows:

a) Independent variable

$$
\begin{aligned}
& \text { - X1 - Information Quality } \\
& \text { - X2 - System Quality } \\
& \text { - X3 - Quality of Service } \\
& \text { - X4 - Intensity of Use }
\end{aligned}
$$

b) Dependent Variable Y (X5)- User Satisfaction

Test criteria $\mathrm{T}$ test is that if the tcount $>$ ttable then $\mathrm{H} 1$ is accepted and Ho is rejected, and if the tcount <ttable then H1 is rejected and Ho is accepted.
The value of the table can be seen from the statistical table with a significance value of $0.05 / 2=0.025$ and degrees of freedom $\mathrm{df}=28-4-1=23$ is 2.069 .

Following are the results of the description of each hypothesis:

1) Information quality variable test results that: Information Quality does not affect User Satisfaction obtained from the Mobile Cloud Learning System. This is evidenced by the value of tcount < ttable $(0.811<2.069)$ which means $\mathrm{H} 1$ is rejected.

2) System quality variable test results that system quality: does not affect User Satisfaction obtained from the Mobile Cloud Learning System. This is evidenced by the value of tcount <ttable $(-1.145<2.069)$ which means H1 is rejected.

3) Time service variable testing results that service: Quality does not affect User Satisfaction obtained from the Mobile Cloud Learning System. This is evidenced by the value of tcount <ttable $(1,157<2,069)$ which means $\mathrm{H} 1$ is rejected.

4) Usage intensity variable testing results that usage: Intensity affects the User Satisfaction obtained from the Mobile Cloud Learning System. This is evidenced by the value of $t>t$ table (3.094> 2.069) which means that Ho is rejected

7) Joint regression coefficient tes (test $f$ ) - 3: Joint regression tests are used to determine the effect together between the dependent variable $(\mathrm{X})$ on the dependent variable (Y). The F Test results can be seen in Table VII as follows:

\section{Satisfaction}

a) Predictors (Independent): Usage Intensity, User

\section{b) Dependent Variable: Net Benefits}

Based on the $\mathrm{F}$ test results from the Table VII using a significance level of 0.05 and df 1 (number of variables -1) df $1=3-1=2$ and df $2(n k-1)$ or $28-2-1=25$ (where $n=$ number of respondents, $\mathrm{k}=$ number of independent variables) read from table $\mathrm{F}$ of 3.39 .

TABLE. V. F TEST RESULT

\begin{tabular}{|l|}
\hline F Count Value \\
\hline 9.255 \\
\hline
\end{tabular}

TABLE. VI. T TEST RESUlT

\begin{tabular}{|l|l|l|}
\hline Variable & $\mathrm{t}$ count & $\mathrm{t}$ table \\
\hline $\mathrm{X} 1$ & 0.811 & 2.069 \\
\hline $\mathrm{X} 2$ & -1.045 & 2.069 \\
\hline $\mathrm{X} 3$ & 1.157 & 2.069 \\
\hline $\mathrm{X} 4$ & 3.094 & 2.069 \\
\hline
\end{tabular}

TABLE. VII. F TEST RESULT

\begin{tabular}{|l|}
\hline F count value \\
\hline 18.137 \\
\hline
\end{tabular}


For testing criteria if $\mathrm{F}$ arithmetic $<\mathrm{F}$ table, then $\mathrm{Ho}$ is accepted and if Fcount $>\mathrm{F}$ table then Ho is rejected.

From the $\mathrm{F}$ test results obtained Fcount of 18.137, then Fcount> Ftable (18.137> 2.8), then Ho is rejected and $\mathrm{H} 1$ is accepted. So it can be concluded that Intensity of Use and User Satisfaction jointly influences with Net Benefits.

8) Partial regression coefficient test ( $t$ test): $\mathrm{T}$ test is used to determine partially the independent variable (X) significantly influences the dependent variable (Y). Test results $f$ using multiple linear regression can be seen in Table VIII as follows:

TABLE. VIII. T TEST RESULT

\begin{tabular}{|l|l|l|}
\hline Variable & $\mathrm{t}$ count & $\mathrm{t}$ table \\
\hline $\mathrm{X} 4$ & 0.682 & 2.060 \\
\hline $\mathrm{X} 5$ & 3.406 & 2.060 \\
\hline
\end{tabular}

a) Independent Variable

$$
\begin{aligned}
& \text { X4 - Intensity of Use } \\
& \text { X5 - User Satisfaction }
\end{aligned}
$$

b) Dependen Variable Y (X6)- Net Benefits

Test criteria $\mathrm{T}$ test is that if the tcount $>$ ttable then $\mathrm{H} 1$ is accepted and Ho is rejected, and if the tcount <ttable then H1 is rejected and Ho is accepted.

For the value of $\mathrm{t}$ table can be seen from the statistical table with a significance value of $0.05 / 2=0.025$ and degrees of freedom df $=28-2-1=25$ is 2.0 .

Following are the results of the description of each hypothesis:

1) User intensity variable test results that user intensity: does not affect the Net Benefits obtained from Sthe Mobile Cloud Learning System. This is evidenced by the value of $\mathrm{t}<\mathrm{t}$ table $(0.682<2.060)$ which means $\mathrm{H} 1$ is rejected.

2) User satisfaction variable test results that user: Satisfaction affects the Net Benefits obtained from the Mobile Cloud Learning System. This is evidenced by the value of $t>t$ table $(3.406<2.060)$ which means H1 is accepted.

\section{CONCLUSION AND SUGGESTIONS}

\section{A. Conclusions}

Based on the $f$ and $t$ test results it can be seen that Information Quality, System Quality, Service Quality, together affect the Intensity of Use in the Mobile Cloud Learning System process, while individually do not affect the Intensity of use in the Mobile Cloud Learning System implementation.

By used $\mathrm{f}$ and t test results it can be seen that Information Quality, System Quality, Service Quality, and Intensity of Use together affect user satisfaction. Information quality, system quality and service quality do not affect User in the Mobile Cloud Learning System implementation.

By calculated $\mathrm{f}$ and $\mathrm{t}$ test results it can be seen that Intensity of Use and user satisfaction together affect Net
Benefits, user intensity does not affect Net Benefit. User Satisfaction influences Net Benefits in the Mobile Cloud Learning System implementation.

\section{B. Suggestions}

Mobile cloud learning needs to be improved, especially on smart notification and teleconference features. In addition, this system also needs to be hosted on a server that has large storage and bandwidth specifications so that multimedia files can run well.

\section{ACKNOWLEDGMENTS}

We would like thank to the Ministry of Research, Technology, and Higher Education for granted funding through Penelitian Kerjasama Perguruan Tinggi (PKPT), No 084/L6/AK/SP2H/PENELITIAN/2019.

\section{REFERENCES}

[1] A. S. A. Y. A.-A. Ivelina Peneva and Krasimir Yordzhev, "Student's Readiness for E-learning in the Universities in Yemen," Science and Technology Publishing (SCI \& TECH), vol. 1, no. 8, August. 2017.

[2] M. Al-Emran, H. M. Elsherif, and K. Shaalan, "Investigating attitudes towards the use of mobile learning in higher education," Computers in Human Behavior, vol. 56, pp. 93-102, Mar. 2016, doi: 10.1016/j.chb.2015.11.033.

[3] W. G. Alghabban, R. M. Salama, and A. H. Altalhi, "Mobile cloud computing: An effective multimodal interface tool for students with dyslexia," Computers in Human Behavior, vol. 75, pp. 160-166, Oct. 2017, doi: 10.1016/j.chb.2017.05.014.

[4] A. Chavoshi and H. Hamidi, "Social, individual, technological and pedagogical factors influencing mobile learning acceptance in higher education: A case from Iran," Telematics and Informatics, vol. 38, pp. 133-165, May 2019, doi: 10.1016/j.tele.2018.09.007.

[5] A. Drigas, G. Kokkalia, and A. Economou, "Mobile Learning For Preschool Education," International Journal of Interactive Mobile Technologies (iJIM), vol. 10, no. 4, p. 57, Oct. 2016, doi: 10.3991/ijim.v10i4.6021.

[6] B. Ferdousi and J. Bari, "Infusing Mobile Technology into Undergraduate Courses for Effective Learning," Procedia - Social and Behavioral Sciences, vol. 176, pp. 307-311, Feb. 2015, doi: 10.1016/j.sbspro.2015.01.476.

[7] A. I. Khan, H. Al-Shihi, Z. A. Al-khanjari, and M. Sarrab, "Mobile Learning (M-Learning) adoption in the Middle East: Lessons learned from the educationally advanced countries," Telematics and Informatics, vol. 32, no. 4, pp. 909-920, Nov. 2015, doi: 10.1016/j.tele.2015.04.005.

[8] G.-J. Hwang and C.-C. Tsai, "Research trends in mobile and ubiquitous learning: a review of publications in selected journals from 2001 to 2010 : Colloquium," British Journal of Educational Technology, vol. 42, no. 4, pp. E65-E70, Jul. 2011, doi: 10.1111/j.1467-8535.2011.01183.x.

[9] D. S. Dhanalakshmi, S. Suganya, and K. Kokilavani, "Mobile Learning Using Cloud Computing," vol. 2, p. 7, 2014.

[10] C. Venkatesan, P. Karthigaikumar, and S. Satheeskumaran, "Mobile cloud computing for ECG telemonitoring and real-time coronary heart disease risk detection," Biomedical Signal Processing and Control, vol. 44, pp. 138-145, Jul. 2018, doi: 10.1016/j.bspc.2018.04.013.

[11] Y. Karaca, M. Moonis, Y.-D. Zhang, and C. Gezgez, "Mobile cloud computing based stroke healthcare system," International Journal of Information Management, vol. 45, pp. 250-261, Apr. 2019, doi: 10.1016/j.ijinfomgt.2018.09.012.

[12] Y. Mehdipour and H. Zerehkafi, "Mobile Learning for Education: Benefits and Challenges," p. 9.

[13] S. AhmadBhat and S. Al Saleh, "Mobile Learning: A Systematic Review," IJCA, vol. 114, no. 11, pp. 1-5, Mar. 2015, doi: 10.5120/20019-1406.

[14] J. Schreurs, "Mobile e-learning course scenario model on PDA," IJMLO, vol. 2, no. 4, p. 358, 2008, doi: 10.1504/IJMLO.2008.020688. 
[15] G. Clough, A. C. Jones, P. McAndrew, and E. Scanlon, "Informal learning with PDAs and smartphones: Informal learning with PDAs," Journal of Computer Assisted Learning, vol. 24, no. 5, pp. 359-371, Sep. 2008, doi: 10.1111/j.1365-2729.2007.00268.x.

[16] M. Wang, R. Shen, D. Novak, and X. Pan, "The impact of mobile learning on students' learning behaviours and performance: Report from a large blended classroom," British Journal of Educational Technology, vol. 40, no. 4, pp. 673-695, Jul. 2009, doi: 10.1111/j.14678535.2008.00846.x.

[17] S.-S. Liaw, M. Hatala, and H.-M. Huang, "Investigating acceptance toward mobile learning to assist individual knowledge management: Based on activity theory approach," Computers \& Education, vol. 54, no. 2, pp. 446-454, Feb. 2010, doi: 10.1016/j.compedu.2009.08.029.

[18] T. Bansal and D. D. Joshi, "A Study of Students' Experiences of Mobile Learning," p. 8, 2014.

[19] M. Sarrab, "M-learning in Education: Omani Undergraduate Students Perspective," Procedia - Social and Behavioral Sciences, vol. 176, pp. 834-839, Feb. 2015, doi: 10.1016/j.sbspro.2015.01.547.

[20] S. Kattayat, S. Josey, and A. J.V, "Mobile Learning Apps in Instruction And Students Achievement," Int. J. Interact. Mob. Technol., vol. 11, no. 1, p. 143, Jan. 2017, doi: 10.3991/ijim.v11i1.6420.

[21] E. Ibukun and O. Daramola, "A Systematic Literature Review of Mobile Cloud Computing," IJMUE, vol. 10, no. 12, pp. 135-152, Dec. 2015, doi: 10.14257/ijmue.2015.10.12.15.

[22] A. N. Khan, M. L. Mat Kiah, S. U. Khan, and S. A. Madani, "Towards secure mobile cloud computing: A survey," Future Generation Computer Systems, vol. 29, no. 5, pp. 1278-1299, Jul. 2013, doi: 10.1016/j.future.2012.08.003

[23] Priya. A. Kotwal and Adwitiy. R. Singh, "Evolution and effects of mobile cloud computing, middleware services on cloud, future prospects: A peek into the mobile cloud operating systems," in 2012 IEEE International Conference on Computational Intelligence and Computing
Research, Coimbatore, India, 2012, pp. 1-5, doi: 10.1109/ICCIC.2012.6510270.

[24] R. Kumar and S. Rajalakshmi, "Mobile Cloud Computing: Standard Approach to Protecting and Securing of Mobile Cloud Ecosystems," in 2013 International Conference on Computer Sciences and Applications, Wuhan, China, 2013, pp. 663-669, doi: 10.1109/CSA.2013.161.

[25] S. MShamim, A. Sarker, A. Newaz Bahar, and Md. Atiqur Rahman, "A Review on Mobile Cloud Computing," IJCA, vol. 113, no. 16, pp. 4-9, Mar. 2015, doi: 10.5120/19908-1883.

[26] W. H. DeLone and E. R. McLean, "Information Systems Success: The Quest for the Dependent Variable," Information Systems Research, vol. 3, no. 1, pp. 60-95, Mar. 1992, doi: 10.1287/isre.3.1.60.

[27] H. Wang and Z. Hu, "Applying DeLone and McLean Information System Model to Online Consumer Behavior in China," in 2009 International Conference on Management of e-Commerce and eGovernment, Nanchang, China, 2009, pp. 74-77, doi: 10.1109/ICMeCG.2009.86.

[28] K. C. Lee and N. Chung, "Understanding factors affecting trust in and satisfaction with mobile banking in Korea: A modified DeLone and McLean's model perspective," Interacting with Computers, vol. 21, no. 5-6, pp. 385-392, Dec. 2009, doi: 10.1016/j.intcom.2009.06.004.

[29] C. Bossen, L. G. Jensen, and F. W. Udsen, "Evaluation of a comprehensive EHR based on the DeLone and McLean model for IS success: Approach, results, and success factors," International Journal of Medical Informatics, vol. 82, no. 10, pp. 940-953, Oct. 2013, doi: 10.1016/j.ijmedinf.2013.05.010.

[30] H. Irawan and I. Syah, "Evaluation of implementation of enterprise resource planning information system with DeLone and McLean model approach," in 2017 5th International Conference on Information and Communication Technology (ICoIC7), Melaka, Malaysia, 2017, pp. 1-7, doi: 10.1109/ICoICT.2017.8074721. 